\title{
A perspective review of deadly viral diseases: An era of viruses
}

\author{
Abhishek Sharma ${ }^{1 *}$, Sarita J. Bhyan², Abdul Malik ${ }^{2}$ \\ ${ }^{1}$ Department of Quality Control and Assurance, Hakeem Abdul Hameed Centenary Hospital and Hamdard Institute of \\ Medical Sciences and Research, New Delhi, India \\ ${ }^{2}$ Department of Pharmacy Practice, Teerthanker Mahaveer College of Pharmacy, Moradabad, Uttar Pradesh, India
}

Received: 06 June 2021

Revised: 04 July 2021

Accepted: 05 July 2021

\section{*Correspondence:}

Dr. Abhishek Sharma,

Email: scientist.abhi12@gmail.com

Copyright: (C) the author(s), publisher and licensee Medip Academy. This is an open-access article distributed under the terms of the Creative Commons Attribution Non-Commercial License, which permits unrestricted non-commercial use, distribution, and reproduction in any medium, provided the original work is properly cited.

\begin{abstract}
This review article overviewed briefly about the era of deadly viruses. Humans have been combating viruses since before our species had even evolved into its recent form. In some cases of viral infections, vaccines and antiviral drugs have allowed us to treat infections from spreading broadly, and have facilitated to patient recover. But it is far from over to fight the viruses. In recent decades, a number of viruses have sprung from animals to humans and have caused massive outbreaks, claiming thousands of lives such as the virus that led to the 2014-2016 Ebola outbreak in West Africa kills up to $90 \%$ of the population, making it the deadliest member of the Ebola family. But there are some viruses that are equally deadly, and some are even more deadly. Some viruses, including the novel coronavirus currently undergoing global outbreaks, have a low mortality rate but still pose a serious health risk as we have no means of access to the health facilities and scarcity of resources and infrastructure. Here we are reporting such type of ten deadly viruses. those have infected humans within last 50 years.
\end{abstract}

Keywords: Deadly viral diseases, Ebola, Antiviral drugs, Coronavirus

\section{INTRODUCTION}

A virus can be simply defined as an intracellular parasite. Each viral particle, or viroids consists of a single nucleic acid of ribonucleic acid (RNA) or deoxyribonucleic acid (DNA). The viral genome is surrounded by a protein coat, and is capable of replication only within the living cells of bacteria, animals and plants. We can differentiate viruses on the basis of their types of nucleic acid present in them such as RNA and DNA, even though the nucleic acid is single or double stranded and the presence or absence of an envelope.

Mainly a virus is a microorganism that is smaller than a bacterium that cannot grow or reproduce apart from a living cell. A virus inoculates in the living cells and uses the chemical mechanism of host body to keep itself alive as well as to replicate. ${ }^{1}$

\section{HISTORY OF VIRUSES}

\section{Chikungunya virus}

First described in Africa (Tanzania) in 1954 and then recognized in Asia, it was accountable for widespread outbreaks on these two continents from the 1960s to the 1980 s, prior to a period of relative stillness over the following 20 years. Its global emergence started in 2004. A major outbreak first spread from Eastern Africa, in Kenya, to most islands in the Indian Ocean in 2005-2006. Chikungunya virus (CHIKV) reach progressively toward Asia, disturbing India since 2006. ${ }^{2}$ The first reported outbreak of CHIKV in India was in Calcutta city in 1963 
and the last outbreak occurred in Barsi in 1973. The virus appeared again in India in December, 2005, and is spreading continuously. The Indian government has reported $13,91,165$ suspected CHIKV cases in 12 states in the country. We feel this is a gross underestimate because no systematic surveillance system for CHIKV existed until August, 2006, there are only two laboratories for virological testing for the whole country, and most private doctors do not report cases of the disease. ${ }^{3}$

The clinical sickness of chikungunya fever needs to be differentiated from dengue and its variants. Rashes occur in both the diseases but are more common in dengue in which, decreased platelet count leads to the severe haemorrhagic signs. There is no specific antiviral therapy available for CHIKV. The management is mostly, supportive, bed rest, fluids, and symptoms may be treated with analgesics and antipyretics but not by salicylate. Paracetamol is used to control fever. Anti-inflammatory drugs are also used. Chloroquine has been tried as empirical treatment without any proven efficacy. Rare cases may require hospitalization and appropriate management is done for the complications. All persons affected by the illness should be protected from further mosquito bites to reduce the risk of further transmission of the virus. ${ }^{4}$

Some of the major clinical manifestations of CHIKV are joint swelling, stomatitis, mouth ulcers, exfoliative dermatitis, muscle pain, rashes. Gastrointestinal symptoms are common. Initial biological changes are temporary leukopenia and lymphopenia, mild thrombocytopenia, low rises in C-reactive protein, and hepatic cytolysis. Pathophysiology of CHIKV includes transmission, route of infection and the innate immune response. CHIKV is transmitted in two different cycles: urban and sylvatic. The urban cycle refers to transmission from human to mosquito to human whereas sylvatic transmission is animal to mosquito to human. The primary vector in CHIKV transmission was found to be Aedes aegypti but Aedes albopictus acted as the main vector in a number of outbreaks in Europe. The route of infection of CHIKV in humans includes epithelial and endothelial cells, primary fibroblasts and monocyte-derived macrophages. The most common complications related to the CNS are convulsions, meningoencephalitis, and Guillain-Barré syndrome. The direct role of CHIKV is evident in these early manifestations. Other severe acute complications were reported in 2005: myocarditis, fulminant hepatitis in patients with chronic liver diseases, pancreatitis, acute endocrine disorders, extensive epidermolysis, kidney failures, respiratory failures, and decompensation of cardiovascular diseases. CHIKV raises modern challenges in science, patient care, and public health that should be without delay taken up to bound its current speedy spread and major consequences. ${ }^{2}$

\section{Hepatitis E virus}

Hepatitis E virus (HEV) infection is a worldwide disease. The HEV was discovered in 1983 by investigators of an outburst of unexplained hepatitis in Soviet soldiers in Afghanistan. HEV is possibly the most common cause of acute viral hepatitis in the world. Following an incubation period of 2 to 6 weeks, clinical symptoms of hepatitis develops, with fever and nausea followed by abdominal pain, vomiting, anorexia, malaise, and hepatomegaly. Jaundice occurs in approximately $40 \%$ of patients. There are a number of well-documented small collection of cases from a point-source food outbreak. In addition to the typical hepatic manifestations, $\mathrm{HEV}$ is also responsible for extrahepatic disorders. Extrahepatic clinical manifestations of HEV comprise a series of neurological syndromes, renal injury, pancreatitis, and hematological problems. The neurological manifestations observed in HEV patients are Guillain-Barré syndrome, Bell's palsy, neuralgic amyotrophy, acute transverse myelitis, and acute meningoencephalitis. Impaired renal function was noted in both acute and chronic HEV infections. ${ }^{5}$ Among 227 patients with liver diseases, $52(22.9 \%)$ patients had acute hepatitis E. The diagnosis of acute hepatitis E can be done by detection of $\operatorname{IgM}$ anti-HEV in 48 patients and primary seroconversion to $\mathrm{IgG}$ anti-HEV in recovery in four patients. $^{6}$

Haematological disorders include thrombocytopenia and aplasticanemia as both of them have been reported for acute HEV infection. Studies have revealed important differences in immunological and hormonal responses in pregnant women with fulminant hepatic failure caused due to HEV. HEV replicates in hepatocytes as well as in the small intestine, colon, and lymphnodes, as demonstrated by detection of negative-sense RNA intermediates. ${ }^{5}$ Out of 2,500 population, 102 suffered from acute hepatitis. The symptomatic attack rate was found to be $4.1 \%(102 / 2,500)$. Patients ranged between 22-55 years of age with an average age of 30 years. Patients presented with fatigue (95.6\%), anorexia $(91.3 \%)$, dark urine $(86.9 \%)$, abdominal pain (60.8\%), arthralgia (56.5\%), scleral icterus (47.8\%), nausea $(47.8 \%)$, fever $(47.8 \%)$, loose stools $(43.4 \%)$, pruritis $(43.4 \%)$, and vomiting $(34.7 \%){ }^{7}$

HEV has also been detected in blood products. A total of $0.7 \%$ of plasma minipools from donors in England were found to be full of HEV RNA, and a prevalence of $10 \%$ was set up for donors in Germany.

Hepatitis E is predominantly common in some Southeast Asian countries (Nepal, Bangladesh, India, and Pakistan), and there have been several large outbreaks in African refugee camps in the last 20 years, such as the recent one in South Sudan, in year 2012-2013. An escalating number of recent studies have exposed that HEV can cause chronic infection that can rapidly results in cirrhosis. A diagnosis of chronic hepatitis used to be considered when persisting HEV replication lasted for at least 6 months. 


\section{Prevention of HEV infection}

HEV1 infection can be prevented by providing clean drinking water and improving the sanitary infrastructure in developing countries. HEV3 infection may also be prohibited by avoiding intake of undercooked meat, especially pork products. Researches showed that HEV gets completely inactivated while heated above $70{ }^{\circ} \mathrm{C} .^{5}$

\section{Dengue virus}

Till the 1980s, India and Sri Lanka reported low number of dengue hemorrhagic fever (DHF) cases despite circulation of all four serotypes of dengue virus (DENV). Since the 1990s the events of DHF has increased. The increase has been recognized to changes in virus family mainly with DENV-2 and DENV-3. DENV-1 is linked with dengue fever (DF) outbreaks and DENV-4 reports are rare. Samples taken from suspected dengue cases are tested for dengue specific IgM, using NIV MAC-ELISA kit, viral RNA using dengue-specific real time RT-PCR and serotyped by multiplex nested RT-PCR test. Respiratory distress has been reported in death cases of dengue. ${ }^{8}$ The first epidemic of clinical dengue-like illness was recorded in Madras (now Chennai) in 1780 and the first virologically proved epidemic of DENV in India occurred in Calcutta and Eastern Coast of India in 1963-1964. The first major spread epidemics of dengue haemorrhagic fever/dengue shock syndrome (DHF/DSS)occurred in India in 1996 involving areas around Delhi and Lucknow and then it increased to all over the country. ${ }^{9}$

Liver damage was found to be one of the major symptoms reported for DHF/DSS cases in India. According to the World Health Organization (WHO), 2011 case definition, dengue infection is suspected in a patient with high fever and other clinical manifestations such as headache, retroorbital pain, myalgia, arthralgia/bone pain, rash. Bleeding manifestations such as petechiae, epistaxis, gum bleeding, hematemesis, melena positive tourniquet test. Leukopenia (WBC $\leq 5,000$ cells/mm3), platelet count $\leq 150,000$ cell/mm3, and hematocrit (Hct) rising 5-10\%.

The modified WHO/SEARO 2011 criteria are as follows

\section{Major criteria}

It includes plasma leakage: elevation of Hct $\geq 20 \%$, detection of ascites, pleural effusion by physical examination, chest film (right lateral decubitus position) or ultrasound.

\section{Minor criteria}

It includes bleeding or positive tourniquet test, and platelet counts $\leq 100,000$ cells $/ \mathrm{mm}^{3}$.

The management of patients with dengue infections depends on the phase of illness, i.e. febrile phase, critical/leakage phase and convalescence phase, as follows:
Febrile phase (early diagnosis of dengue infection)

\section{Clinical signs}

High fever with positive Tourniquet test and leukopenia $\left(\mathrm{WBC} \leq 5,000\right.$ cells $/ \mathrm{mm}^{3}$ ) - positive predictive value 70 $83 \%$.

\section{Rapid diagnostic test}

\section{NS1Ag test}

During the febrile phase (first five days of fever): sensitivity $60-70 \%$, specificity $>99 \%$.

\section{Polymerase chain reaction $(P C R)$}

Good sensitivity and specificity but expensive and not available in most places.

\section{Enzyme-linked immunosorbent assay (ELISA)}

IgM, IgG test - not suitable for early diagnosis because the antibody significantly rises after day 5 of fever.

\section{Management}

Reduction of high fever: paracetamol only, tepid sponge. Promote oral feeding: soft diet, milk, fruit juice, oral rehydration solution (ORS). Avoid IV fluid if there is no vomiting and moderate/severe dehydration. Follow up complete blood count (CBC) every day.

\section{Critical/leakage phase- early detection of plasma leakage/shock}

Thrombocytopenia, i.e. platelet count $\leq 100,000$ cells $/ \mathrm{mm} 3$, is the best indicator for plasma leakage. Admit patients with thrombocytopenia and poor appetite/poor clinical conditions. Chest film - right lateral decubitus technique, ultrasonogarphy or serum albumin $\leq 3.5 \mathrm{gm} \%$ are the alternative ways to detect plasma leakage. Proper IV fluid management during the critical period. Isotonic salt solution in the critical period, e.g. 5\% dextrose in normal saline solution (NSS), 5\% Ringer acetate, 5\% Ringerlactate. The $5 \%$ dextrose in NSS is preferable because the severe cases needing admission are those with poor appetite, nausea/vomiting and abdominal pain. In DSS patients the duration of IV fluid may be 24-36 hours and in non-shock DHF is 48-60 hours. The rate of IV fluid should be adjusted according to clinical vital signs (BP, pulse, respiratory rate, temperature), hematocrit (Hct) and urine output $(0.5 \mathrm{ml} / \mathrm{kg} /$ hour $)$. The IV fluid restoration for DHF grade III is less than that recommended for other kinds of shock, i.e. only $10 \mathrm{ml} / \mathrm{kg} /$ hour, not $20 \mathrm{ml} / \mathrm{kg} /$ hour. In cases with significant bleeding, i.e. $>6-8 \mathrm{ml} / \mathrm{kg}$ ideal body weight in children or $300 \mathrm{ml}$ in adult, blood transfusion is recommended as soon as possible. 


\section{Convalescence phase}

Stop IV fluid when there are signs of recovery: convalescence rash, itching, increase in appetite or $>30$ hours after shock and $>60$ hours after plasma leakage. Some patients may not regain their appetite in this period. This happens may be due to diuresis and loss of potassium in the urine. Potassium supplements may be essential in this phase. Fruit (bananas, oranges) and fruit juice are rich in potassium and are preferred by most patients. In adults, the convalescence period may extend for $2-4$ weeks with fatigue.

The appearance of DENV-4 was reported in recent times in 2003 in Delhi and in 2007 in Hyderabad. The last report of DENV-4 was from Maharashtra in 1975 from Amalner. Based on the studies on dengue in Pune from 2002-2008 describes that DENV-1, 2 and 3 were circulated in Pune. Liver damage was found to be the most important clinical manifestation expressed for DHF/DSS cases in India. The nucleotide diversity detected between the DENV-4 isolates was much higher than that detected for DENV-2 isolates in a specific genotype. ${ }^{8}$ A recent study done at the University of Oxford using a map-based approach to find out the number of dengue cases occurring in various parts of the world, estimated that India has the largest number of dengue cases, with about 33 million evident and another 100 million asymptomatic infections occurring annually. Currently at the most advanced clinical development stage, a tetravalent vaccine based on the chimeric yellow feverdengue virus, has progressed to phase III efficacy studies. The safety and clinical efficacy of the chimeric yellow fever-dengue virus have so far shown promising results. Several other vaccine candidates like living organisms, subunit, DNA and purified inactivated vaccines, are at earlier stages of clinical development. ${ }^{10}$

\section{Rota virus}

Rotaviruses are non-enveloped double-stranded RNA (dsRNA) viruses that have a complex structural design of three concentric capsids that surround a genome of 11 segments of dsRNA. Ten different rotavirus species (A-J) have been classified on the basis of sequence and antigenic differences of VP6. Till date, $32 \mathrm{G}$ genotypes and $47 \mathrm{P}$ genotypes of species of rotavirus have been identified. Although globally, six G types (that is, G1, G2, G3, G4, G9 and G12) and three P types (that is, P4, P6 and P8) predominate. In addition to diarrhoea, rotavirus infection can induce vomiting, malaise and fever. In fact, vomiting is a hallmark of rotavirus disease, causing dehydration and can slow down the effectiveness of therapeutic interventions, such as oral rehydration therapy. Rotaviruses are everywhere and infects almost every child globally near 3-5 years of age. In 2013, rotaviruses were linked with an estimated $>200,000$ fatalities in children $<5$ years of age globally. ${ }^{11}$

Oral rehydration therapy (ORT) is one of the most effective interventions against dehydrating diarrhea and is said to be a major cause of the decline in the global burden of this disease over the past two decades. In India, according to the recent National Family Health Survey, only about 30\% of children have sufficient access to ORT and coverage rates have not improved significantly in recent years. Immunization is one such intervention that has been shown to reach a large segment of the rural population in India, and a rotavirus vaccine that reaches the poorest Indian children could offer an effective measure to reduce the burden of rotavirus diarrhea. ${ }^{12}$ Two different methods are used to estimate the annual number of rotavirus deaths in India. The first method combined national statistics from WHO and UNICEF with data from the Indian rotavirus strain surveillance network, an active diarrheal surveillance system that collects geographically representative information on severe rotavirus disease using standardized protocols for enrolment and diagnostic evaluation at 8 sites (Vellore, Trichy, Pune, Mumbai, Jabalpur, New Delhi, Kolkata and Imphal) across India. ${ }^{13}$

The virus is transmitted mainly through the faecal-oral route, generally by close person-to person contact. Contaminated vehicle (that is, objects that can enable the transmission of pathogens) also have a role in the transmission of rotavirus, especially in out of home care settings and hospitals. Rotavirus infects and replicates in the mature, non-dividing enterocytes in the middle and tip of the villi and in enteroendocrine cells in the small intestine. Rotavirus attachment to host cells is mediated by the outer capsid protein VP4 (through its VP8* domain) and binding partners on the host cell surface, including sialoglycans (such as gangliosides GM1 and GD1a) and histo-blood group antigens (HBGAs). Rotavirus antigen can be detected in stools using ELISA or immunochromatography. The window for the detection of viral shedding using ELISA usually ends within 1 week after the onset of illness, but the virus can be detected for longer periods by more-sensitive assays, such as RT PCR. Vaccination against rotavirus is the best measure to prevent rotavirus disease. Two rotavirus vaccines are broadly used world ᄀwide: the RV5 vaccine, RotaTeq (Merck, USA), and the RV1 vaccine, Rotarix (GlaxoSmithKline, Belgium).

Management of Rota virus includes fluid and electrolyte management (including ORS and intravenous rehydration), dietary management and the use of probiotics, antiemetics, antisecretory drugs and antiviral drugs. Prompt replacement of fluids and electrolytes, spoon by spoon if necessary, with hypo-osmolar ORS (containing 60-75 mmol per litre of sodium in addition to glucose, potassium, chloride and citrate) If ORS is not available, homemade solutions can be given as an alternative which can be prepared using water, sugar and salt. For children living in low-income regions, the WHO recommends daily zinc supplementation for infants and children for 10-14 days, which should be started as soon as the diarrhoea episode has been diagnosed. Combination trials evaluating the simultaneous use of several treatments are lacking. Certainly, improvements in treatment strategies are 
needed, especially in regions where rotavirus-associated deaths occur and where vaccines are underutilized.

\section{Zika virus}

In 1947, a study of yellow fever submitted the first isolation of a new virus from the blood of a sentinel rhesus macaque which was placed in the Zika forest of Uganda. Zika virus remained in relative insignificance for nearly 70 years. In less than the span of just 1 year, Zika virus was introduced into Brazil from the Pacific islands and spread quickly in the population of America. It became the utmost infectious disease associated to human birth defects to be exposed in more than half a century and created such global alarm that the WHO had to announce a public health emergency of international concern. Although Zika virus was isolated on quite a few events from Aedes africanus mosquitoes after its discovery in 1947, there was no warning initially that the virus caused human disease. However, a serosurvey including people of multiple areas of Uganda exposed a $6.1 \%$ seroprevalence of antibodies against Zika virus which recommended that human infection was frequent. Outbreaks happened in 10-16 February 2017 and six laboratories were established to study outbreaks caused by haemorrhagic fever causing viruses.

5839 suspected viral haemorrhagic fever case samples were screened for DEN, CHIKV, and ZIKV and found 811 positives for DEN, $429 \mathrm{CHIKV}$, and 166 samples showed positivity for both.

No samples were found to be positive for ZIKV. Other serosurveys indicated a much broader geographic distribution of human infection including Egypt, East Africa, Nigeria, India, Thailand, Vietnam, the Philippines and Malaysia (near Kuala Lumpur and in East Malaysia [Sabah and Federal Territory of Labuan]). ${ }^{14}$ Human and non-human primates most likely serve as the main reservoirs for the virus but some authors have also reported anti-ZiV antibodies in various mammals (such as, orangoutang, zebras, elephants, etc.) and rodents. ${ }^{15}$

It came in knowledge when a 2007 outbreak on various islands in the state of Yap, Federated States of Micronesia resulted in an estimated 5000 infections among the total population of 6700 . Following outbreaks appeared on other Pacific islands including New Caledonia (2014), Easter Island (2014), Cook Islands (2014), Samoa (2015) and American Samoa (2016). In comparison to these outbreaks, in the past 6 years only periodic cases of Zika virus infection were reported in Thailand, East Malaysia (Sabah), Cambodia, the Philippines and Indonesia. ${ }^{14}$

\section{Influenza virus}

In the 20th century, three influenza pandemics occurred: Spanish influenza in 1918 (17-100 million deaths), Asian influenza in 1957 (two million deaths) and Hong Kong influenza in 1968 (one million deaths. The World Health Organization declared an outbreak of a new type of influenza A/H1N1 to be a pandemic in June 2009. About $15 \%$ acute respiratory infection and $36.2 \%$ severe acute respiratory infection cases were found positive for influenza virus in year 2018. Overall $29.8 \%$ cases were positive for different respiratory viruses (influenza A/H1N1PDM09 (9\%), RSV (6\%), rhino (4\%), PIV (3\%), hMPB $(3 \%)$, adeno $(3 \%)$, influenza B $(2 \%)$ and $\mathrm{H} 3 \mathrm{~N} 2$ $(1 \%)) .{ }^{16}$

In year 2018, in Srinagar, Delhi, Jaipur, Ahmedabad, Rajkot, Maharashtra and Hyderabad etc. positive samples for the influenza virus were carried out. Circulating influenza strains were directly related to the selected influenza vaccine strains, A/California/7/2009 (H1N1), A/Perth/16/2009 (H3N2), and B/Brisbane/60/2008, which remained unchanged for 2011-2012 for the Northern and Southern hemisphere formulations. The 2012-2013 Northern hemisphere formulation changed the H3N2 strain to A/Victoria/361/2011 and the influenza $\mathrm{B}$ strain to B/Wisconsin/1/2010, but sequence information from 2013 circulating viruses from Srinagar was not available to assess vaccine similarity. Influenza vaccine induces a neutralizing antibody response that decreases over time. Thus, the timing of vaccination has a direct effect on vaccine effectiveness. In the northernmost part of India, peak influenza circulation occurs during the winter months; therefore, vaccination during October-November using the Northern hemisphere vaccine formulation should be appropriate. ${ }^{17}$

\section{Pathogenesis of influenza}

Influenza virus enters host cells through specific cellsurface virus receptors consisting of sialic acid (SA) linked to galactose such as SAaGal (avian) or SAaGal (human). In birds receptors are widely distributed in gastrointestinal andrespiratory tracts, but in humans are mostly in upper respiratory tract (URT, nasal mucosa, paranasal sinuses and pharynx etc). Human viruses replicate efficiently in URT, that's why transmit between humans via droplets of URT secretions. Virus replication in the lower respiratory tract contributes to greater pathogenicity. The absence of HPAI-H5N1 receptors in human URT is the main reason that it does not spread from human-to-human. With heavy/repeated exposure it may reach the bronchioles carrying receptors, leading to severe disease with high case-fatality. Since P-09-H1N1 binds to URT receptors, the virus is able to circulate in humans. ${ }^{16}$ Clinical manifestations of influenza virus includes fever, sore throat, cough, nasal congestion, malaise, headache, myalgia and loss of appetite. Nausea, vomiting and diarrhea may rarely occur. The sensitivity and specificity of clinical diagnosis is low. In the majority, the disease is self-limited with recovery within a week. The incubation period is 1-3 days (range 1-7 days).

The management of influenza virus disease can be done by two types of seasonal influenza vaccines which are available - live attenuated and inactivated. The inactivated vaccine is a 'trivalent' containing 2 recent circulating virus 
A subtype representatives and a B subtype. The vaccine formulation (of representative subtypes) is prescribed by the WHO twice every year before the peak influenza season in the southern and northern hemispheres. Over 150 million doses have already been administered. The current FDA-approved vaccine is non-adjuvanted. For children (6 months-10 years), 2 doses and for all above 10, a single dose has been recommended. Antiviral therapy includes neuraminidase inhibitors (NAI) - oseltamivir, zanamivir and peramivir can be used for treatment or prophylaxis. Reports of resistance to oseltamivir are a cause for concern; zanamivir (by inhalation) or peramivir (IV) should be used in oseltamivir-resistant cases. ${ }^{16}$ The interventions designed by the GoI are to prevent entry of P-09-H1N1, to slow down its circulation in urban communities and to reduce case-fatality through diagnosis and antiviral treatment in designated hospitals. There has been a serious attempt by the GoI to educate the public about the need to cover the mouth when sneezing or coughing (to prevent droplets spread in air) and for hand-washing after touching sick persons.

\section{Nipah virus}

During January and February of 2001, an outbreak of febrile illness with altered sensorium was observed in Siliguri, West Bengal, India. The outbreak took place among hospitalized patients, family contacts of the patients, and medical staff of 4 hospitals.

Japanese encephalitis, which is endemic in this area, was initially suspected, but the age group affected and the epidemiologic features recommended a different disease. Laboratory investigations conducted at the time of the outbreak failed to identify an infectious agent. Nipah virus (NiV), a newly arising, zoonotic paramyxovirus, was indicated as the cause of a highly fatal (case-fatality ratio 38-75\%), febrile human encephalitis in Malaysia and Singapore in 1999 and in Bangladesh during the winters of 2001, 2003, and 2004. The natural vector for Nipah virus is recognized to be fruit or bats of the genus Pteropus. Evidence of NiV infection was detected in these bats in Malaysia, Bangladesh, and Cambodia. ${ }^{18}$ On 17 May 2018, a 28 year old male presented to a private facility in Kozhikode district, Kerala state, India with encephalitis. His father and aunt developed fever, body ache, and vomiting on the same day. His brother had died following a similar illness 12 days earlier. The family bunch of encephalitis cases among adults provoked the laboratory to test for $\mathrm{NiV}$ in addition to common causes of encephalitis. Detailed microbiological and virological analysis was done by Manipal centre for virus research (MCVR), Indian council of medical research (ICMR) and virus research and diagnostic laboratory (VRDL), resulted in the diagnosis of NiV infection late in the evening of 18 May 1018. ICMRNational institute of virology (NIV), Pune reconfirmed the results on 20 May 2018. The first recorded outbreak of $\mathrm{NiV}$ in India, affecting 66 persons with a mortality of $68 \%$, occurred in Siliguri, West Bengal in 2001, though it was laboratory-confirmed only in 2006. Considering it's likely to cause public health emergencies, $\mathrm{NiV}$ was selected as one of ten priority diseases in the research and development blueprint of 2018 by the WHO.${ }^{19}$ Detection of NiV can be done by RT-PCR and virus isolation. RNA was extracted from urine samples by using a Qiagen (Valencia, CA, USA) RNA extraction kit. RT-PCR was performed with the superscript one-step RT-PCR kit with Platinum Taq (Invitrogen, Carlsbad, CA, USA). Reaction products were analysed by agarose gel electrophoresis and ethidium bromide straining. PCR products were sequenced by using a cycle sequencing reaction with fluorescent dye terminators (Perkin-Elmer, Applied Biosystems Division, Foster City, CA, USA), and reaction products were analyzed with an ABI 3100 (Perkin-Elmer) automatic sequencer. Sequenced data from multiple reactions were analyzed by using version 10.1 of the genetics computer group package (Accelrys, San Diego, CA, USA). Phylogenetic analyses were performed with PAUP version 4.01 (Sinauer Associates, Sunderland, MA, USA). Two sets of primers were used for RT-PCR reactions. Virus isolation can be done by taking the urine samples on Vero E6cells. To our knowledge, NiV infection has not occurred in the past in India; however, given the proximity of Siliguri to the areas of Bangladesh that experienced NiV outbreaks in 2001, 2002, and 2004, the outbreak is not surprising. ${ }^{18}$ There are presently no drugs or vaccines that particularly treat $\mathrm{NiV}$ infection. WHO has identified Nipah as a priority disease for the WHO research and development. Intensive supportive care is recommended to treat severe respiratory and neurologic complications.

\section{Japenese encephalitis virus}

Japanese encephalitis (JE) is a common mosquito borne viral encephalitis. It is one of the leading forms of viral encephalitis worldwide, which is mostly prevalent in eastern and southern Asia, covering a region with a population of over three billion. Most infections of JE are asymptomatic, but if clinical illness develops, it causes noteworthy morbidity and mortality. Although underreported, JE causes an estimated 50,000 cases and 15,000 deaths annually. JE is a disease of public health importance because of its epidemic potential and high fatality rate. In endemic areas, the highest age-specific attack rates occur in children of 3 to 6 years of age. Approximately one third of patients die, and half of the patients suffer severe neuropsychiatric disability from the disease. The first outbreak of Japanese encephalitis recognized to JEV was reported in Japan in 1871. Major epidemics have been reported about every ten years; in 1924 , over 6,000 cases were documented in a severe epidemic in Japan. In India, epidemics of JE are reported from many parts of the country, and it is considered as a major pediatric problem. The first recognition of JE based on serological surveys was in 1955, in Tamil Nadu, India. A total of approximately 65 cases were reported between 1955 and 1966 in Southern India. Subsequent surveys carried out by the NIV of Pune indicated that approximately half of the population of Southern India has been found to have neutralizing antibodies to the virus. Since 1955, many major outbreaks in different parts of the country have been reported. A major outbreak resulting in 
a $42.6 \%$ fatality rate was reported in the Bankura district of West Bengal in 1973. ${ }^{20}$

The state of Uttar Pradesh (UP) is very common; since the first report of a JE epidemic in 1978. In a major outbreak in UP there were approximately $90 \%$ of all assumed JE cases (6061) and over $89 \%$ deaths (1501) in the country. Approximately 1,145 cases of Japanese encephalitis were reported from 14 districts of UP. About one-fourth $(n=296)$ infected patients died. A large number of cases in the 1988 outbreak in which (adults $22 \%$, children $>10$ years, $60 \%$ of total cases) were found. ${ }^{21}$

\section{Vector and transmission}

The JEV is transmitted to humans by mosquitoes. Mosquito transmission was suspected during the early 1930s; in 1938, Mitamura et al reported isolation from Culex tritaeniorynchus. Many species of Culex mosquitoes can transmit JEV.

For Southern Asia, Eastern Asia, and Southeastern Asia, the main vector of JEV is $C$. tritaeniorhynchus. For Northern Australia, the main vector is C. annulirostris. ${ }^{20}$

Pathogenesis of JEV includes the incubation period of about 6 to 16 days. The factors determining who of all the infected develop the disease are unknown, but could include viral factors such as route of entry, titer, and neurovirulence of the inoculum, and host factors such as age, genetic make-up, general health, and pre-existing immunity. After the bite of an infected mosquito, the virus replicates in the skin and is then transported to regional lymph nodes.

The clinical manifestations of many infections are dependent on whether or not the virus gains access to susceptible cells within the CNS. If the infection is limited to extraneural tissues, the sign and symptoms may be mild or hidden; however, infection of neural tissues by the same agent leads to encephalitis. Therefore, the mechanism by which the virus penetrates the CNS is of prime importance in understanding the pathogenesis of viral diseases. The reason of how JEV crosses the blood-brain barrier is still unknown.

\section{Diagnosis}

Patients with JEV have vivid signs of acute encephalitic syndrome. There are many possible causes of acute encephalitic syndrome thus, laboratory confirmation is essential for the correct diagnosis of JEV, which is not a simple process due to the very low viremia. Diagnosis of $\mathrm{JEV}$ can be completed by virus isolation in cell/tissue culture, antigen detection, and antibody detection.

\section{Prevention and control}

The prevention of JEV is based mainly on two interventions; mosquito control, and by an immunization system.

\section{Treatment}

There is no cure for JEV and treatment is mainly supportive. Patients are not infectious, but should avoid further mosquito bites. A number of antiviral agents have been investigated, including INF alfa-2a68 and diethyldithiocarbamate (a low molecular weight dithiol). However, none of these have convincingly found to improve the outcome of JEV. Effective supportive management has been shown to improve the outcome. The standard management of viral encephalitis should be used. ${ }^{20}$ Japanese encephalitis is still a major health problem in eastern Uttar Pradesh, north India. No antiviral drug against JEV is available.

\section{Ebola virus}

Ebola virus is a negative stranded RNA virus which belongs to the Filoviridae family and is endemic to regions of west and equatorial Africa. These pathogens are primarily transmitted by human-to-human contact with infected body fluids and corpses and may cause severe and acute systemic disease with high mortality. Ebola viruses have large epidemic potential, as shown by the 2013-2016 West African outbreak. This outbreak was unmatched in scale, with more than 28,000 confirmed cases and 11,000 deaths. Only Bundibugyo, Sudan, and Ebola viruses are linked with disease outbreaks in humans. Between 1976 and 2014, these three viruses caused more than 20 known outbreaks linked to human-to-human transmission, with a total of 2400 cases and 1600 deaths. Overall case fatality rate was found to be $25 \%$ for Bundibugyo virus disease, $50 \%$ for Sudan virus disease, and $80 \%$ for Ebola virus disease respectively. The largest ever-recorded outbreak of Ebola virus disease occurred in West Africa from 20132016 following a single Ebola virus initiation from the natural reservoir into the human population. This outbreak mainly affected the areas of Guinea, Sierra Leone, and Liberia and had very high incidence and mortality rates (>28000 cases with $>11000$ deaths). The overall mean case fatality rates in confirmed cases with recorded clinical outcomes were $62.9 \%$ (95\% CI $61.9 \%-64.0 \%$ ). Sexual transmission by survivors of Ebola virus have been reported. Seroprevalence surveys hints that asymptomatic infections can occur. For the diagnosis of Ebola virus disease, real-time RT-PCR tests were the keystone of the laboratory response during the 2013-2016 West African Ebola virus disease outbreak. In general 3-6 days after the onset of the symptoms, the viral load is already high and detectable in the patient's blood through RT-PCR in the vast majority of cases. The common clinical manifestations of Ebola virus disease are moderate fever, malaise, fatigue and body aches followed after a few days by gastrointestinal symptoms, which includes nausea, vomiting, and diarrhea. This phase can reach from mild-tosevere, with fluid loss of up to 5-10 1/day. Some rare symptoms are cough and dyspnoea, conjunctival injection, hiccups, or localised pain (in chest, abdomen, muscles, or joints). Some patients may go into shock, possibly due to hypovolaemia and asystemic inflammatory response. 
However, neurological events are rare which indicates confusion, delirium, and convulsions. Late symptoms include dysphagia, throat pain, and oral ulcers. Renal dysfunction (up to 50\% in the 2013-2016 outbreak), and significant increases in liver enzymes (particularly aspartate and aminotransferase) are common. Creatine phosphokinase and amylase concentrations (with or without clinical pancreatitis) can be increased. Electrolyte abnormalities are common, particularly hypokalaemia, hyponatraemia and hypocalcaemia. Pregnant women face high mortality and a high risk of miscarriage and stillbirth. In September, 2014, WHO inventoried a list of potential drugs developed to Ebola virus disease with revealed antiviral efficacy in vitro or in animal models. These therapeutic drugs are nucleoside and nucleotide analogues, nucleic acid-based drugs, andimmunotherapeutics, including blood-derived products from recovered patients. After the submitted clinical trials, it was determined by WHO that these investigational therapeutics could be offered on an emergency or concerned use basis. A single dose of a recombinant vesicular stomatitis Indiana virus derived vaccine (rVSV-ZEBOV) containing EboGP was found to be immunogenic in phase 1 trials. Another (rVSVZEBOV) was evaluated in a phase 3 trial in guinea using a protocol of ring vaccination. The vaccine was reported highly effective with (efficacy 100\% [95\% CI 68.9-100], $\mathrm{p}=0.0045$ ). As part of WHO's expanded access framework, more than 60,000 individuals were vaccinated until 15 January 2019 , and the vaccination is still ongoing. ${ }^{22}$

\section{Corona virus}

The 2019 novel coronavirus (2019-nCoV) or the severe acute respiratory syndrome corona virus 2 (SARS-CoV-2), has been rapidly spread from its origin in Wuhan city of Hubei Province of China to the rest of the world. Till 05 March 2020 approximately 96,000 cases of coronavirus disease 2019 (COVID-19) and 3300 deaths have been reported. Coronaviruses are enveloped positive sense RNA viruses ranging from $60 \mathrm{~nm}$ to $140 \mathrm{~nm}$ in diameter with spikes like projections on its surface giving it a crown like appearance under the electron microscope; hence the name coronavirus. Four corona viruses namely HKU1, NL63, $229 \mathrm{E}$ and OC43 have been circulating in humans, and generally caused mild respiratory diseases. Earlier, a virus, labelled as severe acute respiratory syndrome coronavirus had affected 8,422 people, mostly in China and Hong Kong which resulted in 916 deaths (mortality rate 11\%) before being contained. Almost a decade later in 2012, the Middle East respiratory syndrome coronavirus (MERS-CoV), that too originated from bat, emerged in Saudi Arabia through dromedary camels as the intermediate host and affected 2494 people and caused 858 deaths (fatality rate $34 \%$ ). The COVID-19 outbreak in china happened due to the common exposure of people to the Huanan wholesale seafood market that also traded live animals as reported in the initial cases.

On 31 December 2019, China, for the first time, notified the outbreak to the WHO and on 1st January the Huanan sea food market was closed. On 7th January the virus was identified as a coronavirus that had $>95 \%$ homology with the bat coronavirus and $>70 \%$ similarity with the SARS$\mathrm{CoV}$. Environmental samples from the Huanan sea food market were also tested positive, indicating that the virus originated from there only. The number of cases started increasing aggressively. However, some of which did not have any kind of exposure to the live animal market, indicative of the fact that human-to-human transmission was taking place. By 23rd January, the 11 million population of Wuhan was put down under lock down with restrictions of entry and exit from the area. Quickly, this lock down was further extended to other cities of Hubei province. Cases of COVID-19 in other countries outside China were reported in people with no history of travel to China suggesting that local human-to-human transmission was happening in these countries. Airports in different countries including India puts in screening mechanisms to detect symptomatic individuals returning from China and putting them in isolation and testing them for COVID-19. On 12th of February, China reported a masse increase in COVID-19 cases by 15,000 cases in a single day. It is important to note that even as the number of new cases has reduced in China recently, they have increased drastically in other countries including South Korea, Italy and Iran. Of those infected people, $20 \%$ are in critical condition whereas $25 \%$ have been recovered, and 3310 cases from which (3013 in China and 297 in other countries) have died. India, which had reported only 3 cases till the date (02 March 2020), has also seen a sudden outburst in cases. By 05 March 2020, 29 cases had been reported; mostly in Delhi, Jaipur and Agra in Italian tourists and their contacts.

Epidemiology of COVID-19 tells that all age groups are prone to this virus. Infection is mainly transmitted through large droplets generated at some point in coughing and sneezing by symptomatic patients but can also occur from asymptomatic patients and before onset of symptoms. Studies have revealed higher viral loads in the nasal cavity as compared to the throat with no difference in viral burden between symptomatic and asymptomatic patients. Coronavirus can remain viable on surfaces for days in favourable atmospheric conditions but can be destroyed in less than a minute using common disinfectants like sodium hypochlorite, hydrogen peroxide etc. Infection is acquired either by inhalation of these droplets or touching surfaces contaminated by them or then touching the nose, mouth and eyes. As per current information, transplacental transmission from pregnant women to their fetus has not been reported. However, neonatal disease due to post natal transmission is described. The incubation period varies from 2 to 14 days (average of 5 days). Studies have recognized angiotensin receptor 2 (ACE2) as the receptor through which the virus enters the respiratory mucosa. The basic case reproduction rate (BCR) is estimated to vary from 2 to 6.47 in various studies. In comparison, the BCR of SARS was 2 and 1.3 for pandemic flu H1N1 in 2009. 
Table 1: 50 years of viral diseases at a glance.

\begin{tabular}{|c|c|c|c|c|c|c|c|c|c|c|}
\hline $\begin{array}{l}\text { Virus } \\
\text { name }\end{array}$ & Origin & $\begin{array}{l}\text { Mode of } \\
\text { transmisson }\end{array}$ & $\begin{array}{l}\text { Phylogenetic } \\
\text { classification }\end{array}$ & Strain of virus & Vector & Mortaliy & Complications & Prevelance & $\begin{array}{l}\text { Pandemic or } \\
\text { endemic }\end{array}$ & $\begin{array}{l}\text { Incubation } \\
\text { period }\end{array}$ \\
\hline $\begin{array}{l}\text { Chikungu } \\
\text { nya virus }\end{array}$ & Africa (Kenya) & $\begin{array}{l}\text { Mosquito } \\
\text { bites }\end{array}$ & Togaviridae & $\begin{array}{l}\text { Arthritogeneticalp } \\
\text { havirus }\end{array}$ & $\begin{array}{l}\text { Aedes } \\
\text { mosquito }\end{array}$ & $\begin{array}{l}82 \% \\
\text { men, } \\
18 \%, \\
\text { women }\end{array}$ & $\begin{array}{l}\text { Meningocephalitis, } \\
\text { myelitis, uveitis }\end{array}$ & $\begin{array}{l}5 \text { lakh case per } \\
\text { year }\end{array}$ & Endemic & 3-7 days \\
\hline $\begin{array}{l}\text { Hepatitis e } \\
\text { virus }\end{array}$ & Afghanistan & $\begin{array}{l}\text { Shellfish or } \\
\text { polluted } \\
\text { water }\end{array}$ & $\begin{array}{l}\text { Orthohepevir } \\
\text { us }\end{array}$ & $\begin{array}{l}\text { Inflammation of } \\
\text { liver }\end{array}$ & $\begin{array}{l}\text { Contaminat } \\
\text { ed food } \\
\text { and } \\
\text { faecally }\end{array}$ & $3.3 \%$ & $\begin{array}{l}\text { Neurological disorder, } \\
\text { liver damage }\end{array}$ & $\begin{array}{l}20 \text { million case } \\
\text { per year } \\
\text { (worldwide) }\end{array}$ & Epidemic & $\begin{array}{l}2 \text { to } 10 \\
\text { Weeks }\end{array}$ \\
\hline Dengue & Asia,Africa & $\begin{array}{l}\text { Through } \\
\text { mosquito } \\
\text { bites }\end{array}$ & Flavivirus & Flavivirus & $\begin{array}{l}\text { Aedes } \\
\text { Agypti }\end{array}$ & $\begin{array}{l}\text { Below } \\
1 \%\end{array}$ & $\begin{array}{l}\text { Cardiomyopathy, } \\
\text { iritis, hepatic injury }\end{array}$ & $\begin{array}{l}\text { 100-400 million } \\
\text { case worldwide }\end{array}$ & Epidemic & 5-7 days \\
\hline Rota virus & $\begin{array}{l}\text { Intestinal } \\
\text { tissue of } \\
\text { children with } \\
\text { diarrohea }\end{array}$ & $\begin{array}{l}\text { Faecal oral } \\
\text { route }\end{array}$ & Reoviridae & G type & $\begin{array}{l}\text { Rotavirus } \\
\text { transmitted } \\
\text { in } \\
\text { environme } \\
\text { nt }\end{array}$ & $4.4 \%$ & $\begin{array}{l}\text { Dehydration, } \\
\text { metabolic acidosis, } \\
\text { electrolyte imbalance }\end{array}$ & $\begin{array}{l}1.7-12 \text { year } \\
(51.4 \%), 2.13- \\
18 \text { year } \\
(25.7 \%), 3.19- \\
24(11.4 \%)\end{array}$ & Epidemic & 24-74 hours \\
\hline Zika virus & 1952 in Africa & $\begin{array}{l}\text { Aedes } \\
\text { aegypti, A. } \\
\text { albopictus, } \\
\text { A. hensilli, } \\
\text { A. } \\
\text { polynesiensis }\end{array}$ & $\begin{array}{l}\text { Arthropod } \\
\text { borne virus }\end{array}$ & Flaviviridae & $\begin{array}{l}\text { Water } \\
\text { holding } \\
\text { containers }\end{array}$ & $8.3 \%$ & $\begin{array}{l}\text { Guillianbaree } \\
\text { syndrome, neuropath, } \\
\text { myelitis, } \\
\text { meningoencephalitis, } \\
\text { acute myelitis }\end{array}$ & $\begin{array}{l}5000 \text { cases per } \\
\text { year in India }\end{array}$ & Pandemic & $\begin{array}{l}\text { Less than } 1 \\
\text { week }\end{array}$ \\
\hline $\begin{array}{l}\text { Influenza } \\
\text { virus }\end{array}$ & 1918 in Spain & $\begin{array}{l}\text { Cough } \\
\text { sneeze or talk }\end{array}$ & $\begin{array}{l}\text { Alpha } \\
\text { influenza } \\
\text { virus }\end{array}$ & Orthomyxoviridae & $\begin{array}{l}\text { A } \\
\text { respiratory } \\
\text { disease } \\
\text { pathogen }\end{array}$ & $\begin{array}{l}38 \\
\text { million }\end{array}$ & $\begin{array}{l}\text { Dehydration, } \\
\text { pneumoni, lung } \\
\text { infection }\end{array}$ & $\begin{array}{l}\text { More than } 10 \\
\text { milion cases in } \\
\text { India }\end{array}$ & Pandemic & 1-4 days \\
\hline $\begin{array}{l}\text { Nipah } \\
\text { virus }\end{array}$ & $\begin{array}{l}1999 \text { in } \\
\text { Malaysia }\end{array}$ & $\begin{array}{l}\text { Direct } \\
\text { contact with } \\
\text { infected } \\
\text { animals }\end{array}$ & $\begin{array}{l}\text { Genus } \\
\text { henipavirus }\end{array}$ & Henapavirus & $\begin{array}{l}\text { Bats or } \\
\text { pigs }\end{array}$ & $40-75 \%$ & $\begin{array}{l}\text { Encephalitis, mental } \\
\text { confusion }\end{array}$ & $15-55 \%$ in India & Pandemic & 4-14 days \\
\hline $\begin{array}{l}\text { Japanese } \\
\text { encephaliti } \\
\text { s }\end{array}$ & 1871 in Japan & $\begin{array}{l}\text { Culex } \\
\text { species } \\
\text { mosquito }\end{array}$ & Flavivirus & GV, GIV, GII, GI & $\begin{array}{l}\text { Pigs and } \\
\text { wading } \\
\text { birds }\end{array}$ & $18.7 \%$ & $\begin{array}{l}\text { Seizures, swallowing } \\
\text { problem, memory } \\
\text { problem }\end{array}$ & $\begin{array}{l}\text { Fewer than } \\
5000 \text { cases in } \\
\text { India }\end{array}$ & Endemic & 5-15 days \\
\hline $\begin{array}{l}\text { Ebola } \\
\text { virus }\end{array}$ & $\begin{array}{l}1976 \text { near } \\
\text { Ebola river }\end{array}$ & $\begin{array}{l}\text { Infected } \\
\text { blood or } \\
\text { body fluids }\end{array}$ & Filoviridae & $\begin{array}{l}\text { Zaire ebolaviru, } \\
\text { Sudan virus, } \\
\text { Bundibugyo virus }\end{array}$ & Bats & $20-80 \%$ & $\begin{array}{l}\text { Organ failure, severe } \\
\text { bleeding, coma, } \\
\text { seizures }\end{array}$ & $\begin{array}{l}\text { Fewer than } \\
5000 \text { cases in } \\
\text { India }\end{array}$ & & 2-21 days \\
\hline $\begin{array}{l}\text { Corona } \\
\text { virus }\end{array}$ & $\begin{array}{l}\text { Wuhan city } \\
\text { (China) }\end{array}$ & $\begin{array}{l}\text { Respiratory } \\
\text { droplets }\end{array}$ & Nidovirus & 229E (alpha) & $\begin{array}{l}\text { Respiratory } \\
\text { droplets }\end{array}$ & 145581 & $\begin{array}{l}\text { Acute respiratory } \\
\text { failure, pneumonia, } \\
\text { septic shock, cardiac } \\
\text { injury }\end{array}$ & $\begin{array}{l}10037179 \text { cases } \\
\text { in India }\end{array}$ & Pandemic & $1-13$ days \\
\hline
\end{tabular}


The common clinical features of COVID-19 included fever (not in all), cough, sore throat, headache, fatigue, myalgia and breathlessness. Conjunctivitis has also been reported. Complications witnessed of COVID-19 included acute lung injury, ARDS, shock and acute kidney injury. Recovery started in the 2nd or 3rd week. Precisely, diagnosis of COVID-19 can be done by specific molecular tests on respiratory samples (such as throat swab/nasopharyngeal swab/sputum/endotracheal aspirates and bronchoalveolar lavage). Virus may also be detected in the stool and in severe cases, in the blood also. The differential diagnosis includes all types of respiratory viral infections influenza, parainfluenza, respiratory syncytial virus (RSV), adenovirus, human meta-pneumovirus and bacterial infections. ${ }^{23}$

\section{DISCUSSION}

In this study we have discussed about the different types of viruses inoculating in the world. We have taken chikungunya virus, hepatitis E virus, dengue virus, rotavirus, Zika virus, influenza virus, Nipah virus, Japanese encephalitis, Ebola virus and corona virus respectively. The study of these viruses is done in order to compile the data taken from various review articles which tells about the origin, mode of transmission, phylogenetic classification, and strains of virus, vectors, mortality rates, prevalence rates and incubation periods of the viruses.

\section{CONCLUSION}

In this study we have taken 10 different viruses to find out which one of them is causing higher no of deaths per year. According to the data we have compiled from various review articles we came to acknowledge that the Influenza virus caused approximately 38 million of deaths which is the highest mortality rate amongst the 10 viruses. On the other hand the lowest mortality was found to be of hepatitis E virus causing roughly $3.3 \%$ deaths.

\section{Funding: No funding sources Conflict of interest: None declared Ethical approval: Not required}

\section{REFERENCES}

1. Louten J. Virus Structure and Classification. Essential Human Virology. 2016;19-29.

2. Simon F, Javelle E, Oliver M, Leparc-Goffart I, Marimoutou C. Chikungunya virus infection. Curr Infect Dis Rep. 2011;13(3):218-28.

3. Mavalankar D, Shastri P, Raman P. "Chikungunya Epidemic in India: a Major Public-Health Disaster." Lancet Infect Dis. 7.5 2007;306-7.

4. Lahariya C, Pradhan SK. Emergence of chikungunya virus in Indian subcontinent after 32 years: A review. J Vector Borne Dis. 2006;43(4):151-60.
5. Kamar N, Dalton HR, Abravanel F, Izopet J. Hepatitis $\mathrm{E}$ virus infection. Clin Microbiol Rev. 2014;27(1):116-38.

6. Khuroo MS, Rustgi VK, Dawson GJ, Mushahwar IK, Yattoo GN, Kamili S, Khan BA. Spectrum of hepatitis $\mathrm{E}$ virus infection in India. $\mathrm{J}$ Med Virol. 1994;43(3):281-6.

7. Majumdar MM, Singh M, Pujhari S, Bhatia D, Chawla Y, Ratho R. Hepatitis E virus antigen detection as an early diagnostic marker: Report from India. J Med Virol. 2013;85.

8. Bharaj P, Chahar HS, Pandey A, Diddi K, Dar L, Guleria R, Kabra SK, Broor S. Concurrent infections by all four dengue virus serotypes during an outbreak of dengue in 2006 in Delhi, India. Virol J. 2008;5:1.

9. Gupta N, Srivastava S, Jain A, Chaturvedi UC. Dengue in India. Indian J Med Res. 2012;136(3):37390.

10. Gupta E, Ballani N. Current perspectives on the spread of dengue in India. Infect Drug Resist. 2014;7:337-42.

11. Crawford SE, Ramani S, Tate JE, Parashar UD, Svensson L, Hagbom M, et al. Rotavirus infection. Nat Rev Dis Primers. 2017;3:17083.

12. Jain V, Parashar UD, Glass RI. Epidemiology of rotavirus in India. Indian J Pediatr. 2001;68:855-62.

13. Tate JE, Chitambar S, Esposito DH, Sarkar R, Gladstone B, Ramani S, et al. Disease and economic burden of rotavirus diarrhoea in India. Vaccine. 2009;27:18-24.

14. Petersen LR, Jamieson DJ, Powers AM, Honein MA. Zika Virus. N Engl J Med. 2016;374(16):1552-63.

15. Mourya DT, Shil P, Sapkal GN, Yadav PD. Zika virus: Indian perspectives. Indian J Med Res. 2016;143(5):553-64.

16. John TJ, Moorthy M. 2009 pandemic influenza in India. Indian Pediatr. 2010;47(1):25-31.

17. Koul PA, Broor S, Saha S, Barnes J, Smith C, Shaw M, Chadha M, Lal RB. Differences in influenza seasonality by latitude, northern India. Emerg Infect Dis. 2014;20(10):1723-6.

18. Chadha MS, Comer JA, Lowe L, Rota PA, Rollin PE, Bellini WJ, Ksiazek TG, Mishra A. Nipah virusassociated encephalitis outbreak, Siliguri, India. Emerg Infect Dis. 2006;12(2):235-40.

19. Arunkumar G, Chandni R, Mourya DT, Singh SK, Sadanandan R, Sudan P, Bhargava B; Nipah Investigators People and Health Study Group. Outbreak Investigation of Nipah Virus Disease in Kerala, India, 2018. J Infect Dis. 2019;219(12):186778.

20. Tiwari S, Singh RK, Tiwari R, Dhole TN. Japanese encephalitis: a review of the Indian perspective. Braz J Infect Dis. 2012;16(6):564-73.

21. Kumari R, Joshi PL. A review of Japanese encephalitis in Uttar Pradesh, India. WHO South East Asia J Public Health. 2012;1(4):374-95.

22. Malvy D, McElroy AK, de Clerck H, Günther S, van Griensven J. Ebola virus disease. Lancet. 2019;393(10174):936-48. 
23. Singhal T. A Review of Coronavirus Disease-2019 (COVID-19). Indian J Pediatr. 2020;87(4):281-6.
Cite this article as: Sharma A, Bhyan SJ, Malik A. A perspective review of deadly viral diseases: an era of viruses. Int J Basic Clin Pharmacol 2021;10:103848. 